ЧЕТИРИ ДЕЦЕНИЈЕ РАДА РАДИОЛОШКОГ ОДСЕКА ПРИ ВИСОКОЈ ЗДРАВСТВЕНОЈ ШКОЛИ СТРУКОВНИХ СТУДИЈА У БЕОГРАДУ

Мирослав Мишић ${ }^{1}$, Катарина Китановић²

\title{
FOUR DECADES OF WORK IN DEPARTMENT OF RADIOLOGY AT THE HIGH MEDICAL COLLEGE OF PROFESSIONAL STUDIES IN BELGRADE
}

Miroslav Mišić, Katarina Kitanović

\section{Сажетак}

Улагањем у образовање кадра за потребе радиолошке технике свака нација обезбеђује свом становништву оптимално излагање X-зрачима када је то потребно у ииљу излечењь појединаца или периодичне провере здравственог стања становништва.

Циљ овог рада је да дођемо до сазнана о образовану кадра у области радиолошке технике у Србији.

Све до почетка тридесетих година двадесетог века на рендген апаратима су радили само лекари, а тада се појављују „,први рендген техничари“, који нису били школовани већ приучени за рад на рендген апаратима. Педесетих година прошлог века почиье школовање рендген техничара у средњим школама. Одсек виших радиолошких техничара при Вишој медиичнској иколи у Београду почео је са радом 1974. године.

Ове 2014. године Одсек за радиологију при Високој здравственој школи струковних студија у Београду прославиће 40 година рада.

Први стручни назив овог профила био је „виши рендген техничар“. Године 1977. уведен је нови стручни назив „виши радиолошки техничар “. Стручни назив „,струковни медищински радиолог“ уведен је 2007. године.

\section{Summary}

By investing in the education of personnel for radiological techniques each nation provides its citizens optimal exposure to $X$-rays if necessary in order to cure individuals or periodic assessment of the health status of the population.

The aim of this study was to come to the knowledge of the staffin the field of radiological techniques in Serbia.

Until the beginning of the thirties of the twentieth century, the X-ray machine was operated by physicians and then ,the first $X$-ray technicians" appeared who were not formally trained but only learned how to operate the X-ray machine. In the fifties the training in X-ray technician schools began. Department for senior radiographers at the High Medical School in Belgrade started its work in 1974.

In 2014 the Department of Radiology at the High Medical School in Belgrade will celebrate its 40th anniversary.

The first professional title was ,, senior $x$-ray technician “. In 1977 a new professional name of „radiological technician" was introduced. Professional title „professional medical radiologist" was introduced in 2007.

\footnotetext{
${ }^{1}$ Мирослав Мишић, Висока здравствена школа струковних студија, Београд.

${ }^{2}$ Катарина Китановић, Средња техничка ПТТ школа, Београд.
} 
Виша медищинска школа у Београду акредитована је одлуком Комисије за акредитаичју и проверу квалитета Републике Србије 2007. године као Висока здравствена школа струковних студија у Београду. Овом акредитаиијомнашодсекдобијанови стручни назив и право на струковну специјализацију. Априла 2012. године радиолошки одсек је успешно прошао поновну акредитащију. Тиме је још једном потврђен квалитет одсека и сматрали смо да наш одсек заслужсује спеиијализащију. Донета је одлука да се аплицира за струковну специјализачију област Савремене дијагностичке технике у радиологији. Поменута специјализачија је одобрена новембра 2012. године.

До априла 2012. године по плану и програму Више медицинске школе у Београду дипломирало је 1.855 студената и стекло звање виши радиолошки техничар. Од 2007. године до априла 2012. године струковне студије је завриило 140 студената и стекло зване струковни медицински радиолог. У истом периоду 415 виших радиолошких техничара је „ускладило своју диплому" са планом и програмом струковних студија, и такође стекло звање струковни медицински радиолог.

Прошли смо дуг пут и идемо још даље, јер доба које је пред нама припада радиолошкој техници, а то нас све заједно обавезује.

Кључне речи: радиолошка техника, образоване, оптимално излагане становништва $X$-зрацима у медицинске сврхе.
High Medical College in Belgrade was accredited by the decision of the Commission for Accreditation and Quality Assurance of the Republic of Serbia in 2007 as the High Medical College of Professional Studies in Belgrade. The accreditation of gave our department a new professional title and the right to vocational specialization. In April 2012 the Radiology department has successfully passed the reaccreditation. The quality of our department was once again confirmed and we felt that our department deserves a specialization. The decision was made to apply for vocational specialization in the field of modern diagnostic techniques in radiology. The aforementioned specialization was approved in November 2012.

Until April 2012 the High Medical School has promoted 1855 students to radiological technicians. From 2007 to April 2012140 students comleted vocational studies became $a$ "professional medical radiologist". In the same period 415 senior radiographers „harmonized" their degree with the program of professional studies and also obtained the title of ",professional medical radiologist".

We went a long way and we're going even further, because the time that is before us belongs to radiology techniques and it represents a challenge for all of us.

Keywords: radiologytechniques, education, optimal exposure of the population to $X$-rays for medical purposes.

\section{УВОД}

$\mathrm{J}$ онизујуће зрачење умедицини је веома ефикасно дијагностичко и терапијско средство, и поред тога што је после само шест месеци од Рендгеновог открића $\mathrm{X}$-зрака српски научник Никола Тесла указао на штетност ове методе. Јуна 1896. године Никола Тесла је упозорио експериментаторе да не треба да буду у близини рендгенске цеви. Ово је уједно и фундаментални прин- цип заштите од X-зрака. ${ }^{(1)}$ Поред развоја алтернативних дијагностичких метода за потребе медицине, дијагностичке методе које се базирају на примени X-зрака остале су готово незаменљиве. Стање се вероватно неће променити у скорој будућности, с обзиром на то да се уводе нове дијагностичке и терапијске методе које се такође базирају на примени X-зрака, а са циљем да очувају здравље људској врсти.(2) Савремене техничке иновације у медицини омогућавају ми- 
нимално озрачивање пацијената и професионално изложених лица у односу на период одмах после открића X-зрака, уз високу вредност дијагностичке информације и терапијског дејства. Међутим, не постоји доза јонизујућег зрачења која је потпуно безопасна, нити и једно заштитно средство које би у потпуности отклонило штетан ефекат X-зрака. ${ }^{(1)}$ Оправданост употребе $\mathrm{X}$-зрака у медицини постоји када је штета коју може проузроковати мања у односу на користи коју доноси за здравље пацијента. Ово правило се треба примењивати и на скрининг програме. ${ }^{(2)}$ Један од предуслова за поштовање поменутог правила, односно правилан избор и спровођење радиолошке процедуре је образовање кадра у области радиолошке технике. Улагањем у овај кадар свака нација обезбеђује свом становништву оптимално излагање $\mathrm{X}$-зрацима уколико је то потребно у циљу излечења појединаца или периодичне провере здравственог стања становништва. ${ }^{(3)}$

Циљ овог рада је да дођемо до сазнања о образовању кадра у области радиолошке технике у Србији.

\section{ОБРАЗОВАНЕ КАДРА У ОБЛАСТИ РАДИОЛОШКЕ ТЕХНИКЕ У СРБИЈИ}

На први рендген апарат у Србији чекало се само две године од проналаска X-зрака, што значи да медицинска радиологија у Србији датира од 1897. године. Све до почетка тридесетих година двадесетог века на рендген апаратима су радили само лекари, а тада се појављују „први рендген техничари“, који нису били школовани већ приучени за рад на рендген апаратима. Педесетих година прошлог века почиње школовање рендген техничара у средњим школама, које је убрзо прекинуто због поштовања Закона о заштити од јонизујућег зрачења. У Београду су због тога организовани четворомесечни курсеви које је водио професор Магарашевић. Одсек виших радиолошких техничара при Вишој медицинској школи у Београду почео је са радом 1974. године. Осамдесетих година двадесетог века због недостатка кадрова ишколовано је још неколико генерација радиолошких техничара у средњим школама. Крајем деведесетих година прошлог века у Ћуприји при Вишој медицинској школи постојао је Одсек виших радиолошких техничара, где је ишколовано само неколико генерација. ${ }^{(4,5)}$

\section{Радиолошки одсек од 1974. године до данас}

Радиолошки одсек при Високој здравственој школи струковних студија у Београду текуће 2014. године слави 40 година успешног рада.

Као што је већ поменуто, Одсек виших радиолошких техничара при Вишој медицинској школи у Београду почео је са радом 1974. године. У складу са развојем радиологије и праћењем европских и светских стандарда, наставни план и програм је од 1974. године до данас реформисан више пута (1977, 1987, 1990, 1992, 2001, 2007. и 2012. године). Први стручни назив био је „виши рендген техничар“. 1977. године уводи се нови стручни назив „виши радиолошки техничар“. ${ }^{(4,5)}$ Стручни назив „струковни медицински радиолог“ уведен је 2007. године. ${ }^{(6)}$

Шефови Одсека од оснивања до данас били су: проф. др Милета Магарашевић (1974-1976), проф. др Миодраг Јашовић (1976-1980), мр Борка Стојковић (1980-1986) и проф. др Милан Милановић од 1986. године. ${ }^{(4,5)}$

\section{Радиолошки одсек и струковне студије}

Виша медицинска школа у Београду акредитована је одлуком Комисије за акредитацију и проверу квалитета Републике Србије (одлука број 612-00-125/2006-04 од 30.4.2007) као Висока здравствена школа струковних студија у Београду. Овом акредитацијом наш одсек добија нови стру- 
чни назив Струковни медицински радиолог. Основне Струковне студије трају три године, а наставни план на одсеку Струковни медицински радиолог има 24 предмета. Априла 2012. године радиолошки одсек је успешно прошао поновну (редовну на сваких пет година) акредитацију чиме је још једном потврђен квалитет овог одсека.

У оквиру струковних студија предвиђена је и струковна специјализација. Наш смер је имао право на специјализацију од 2007. године. Сматрали смо да наш смер заслужује специјализацију, међутим били смо свесни да она не сме бити исхитрена већ добро припремљена и правилно реализована. Из тог разлога смо одлучили да спроведемо истраживање под називом „Потреба струковних медицинских радиолога за специјализацијом у Србији“. Руководилац истраживања био је мр Мирослав Мишић. Анкетирање је спроведено преко сајта Удружења радиолошких техничара и техничара нуклеарне медицине Србије (http://www.radteh.org.rs/), а остала струковна удружења су подржала анкетирање. Прикупљање емпиријске грађе обављено је од 19.2.2012. до 21.3.2012. године. Треба истаћи да је ово прво и за сад једино истраживање овакве врсте у оквиру Високе здравствене школе струковних студија у Београду. Истраживањем смо дошли до драгоцених података који су били детаљно анализирани. ${ }^{(6)}$

На већу Одсека априла 2012. године на челу са проф. др Миланом Милановићем донета је одлука да се аплицира за струковну специјализацију, област Савремене дијагностичке технике у радиологији. Поменута специјализација је одобрена од стране Комисије за акредитацију и проверу квалитета Републике Србије новембра 2012. године. Специјализација траје два семестра, има 10 предмета и доноси 60 ЕСПБ. ${ }^{(7)}$

\section{Радиолошки одсек кроз бројке}

До априла 2012. године по плану и програму Више медицинске школе у Београду дипломирало је 1.855 студената и стекло звање виши радиолошки техничар. Од 2007. године до априла 2012. године струковне студије је завршило 140 студената и стекло звање струковни медицински радиолог. У истом периоду 415 виших радиолошких техничара је „ускладило своју диплому“ са планом и програмом струковних студија, и такође стекло звање струковни медицински радиолог. ${ }^{(6)}$

Према параметрима пријемног испита за основне студије, радиолошки смер је водећи у оквиру школе. Нпр. на једно понуђено место у просеку се пријаве од 3 до 3,3 кандидата, тако да се сва места попуне у првом пријемном, односно уписном року.

У првом уписном року за специјализацију се пријавило 80 кандидата, што је било више него што је било укупно пријављених кандидата на свим специјализацијама у оквиру Високе здравствене школе струковних студија у Београду у истом уписном року.

\section{ЗАКЈУУАК}

Прошли смо дуг пут и идемо још даље, јер доба које је пред нама припада и радиолошкој техници, а то нас све заједно обавезује. Струковни медицински радиолози остају важан медицински кадар и, с обзиром на њихов мали број на нашем тржишту рада, а велику потребу за овим профилом, неопходно је даље школовање будућих кадрова. Један од могућих праваца развоја је и стварање нових мастер струковних или нових специјалистичких студијских програма. 


\section{ЛИТЕРАТУРА}

1. Томашевић М, Голднер Б: Рендгенско зрачење и заштита у медицинској дијагностици. Веларта, Београд, 1998.

2. Цирај-Бјелац О: Пацијентне дозе и квалитет слике у дијагностичкој радиологији. Задужбина Андрејевић, Београд, 2007.

3. Мишић М: Радиолошки одсек при Високој здравственој школи струковних студија пред велики јубилеј. Зборник радова, Конгрес радиолошких техничара и техничара нуклеарне Србије, Кладово, 2013.

4. Милановић М: Организација и историја радиолошке службе. Ковитом, Београд, 2005.

5. Лазаревић А. (уредник): 50 година

рада, Висока здравствена школа струковних студија у Београду. Народна библиотека Србије, Београд, 2008.

6. Мишић М, Милановић М, Новаковић М: Потреба струковних медицинских радиолога за специјализацијом у Србији. Зборник радова, Конгрес радиолошких техничара и техничара нуклеарне медицине Војводине, Палић, 2012.

7. Програм специјалистичких студија Високе здравствене школе струковних судија у Београду. Преузето ca: http:/www.vzsbeograd.edu.rs/ nastavni-planovi/55-nastvani-planovi/ specijalisticke-strukovne-studije/929specijalista-strukovni-medicinski-radiologoblast-savremene-dijagnosticke-metode-uradiologiji.html. Приступљено 17. априла 2012. године.

Контакт: Мирослав Мишић, Висока здравствена школа струковних студија, Београд. 